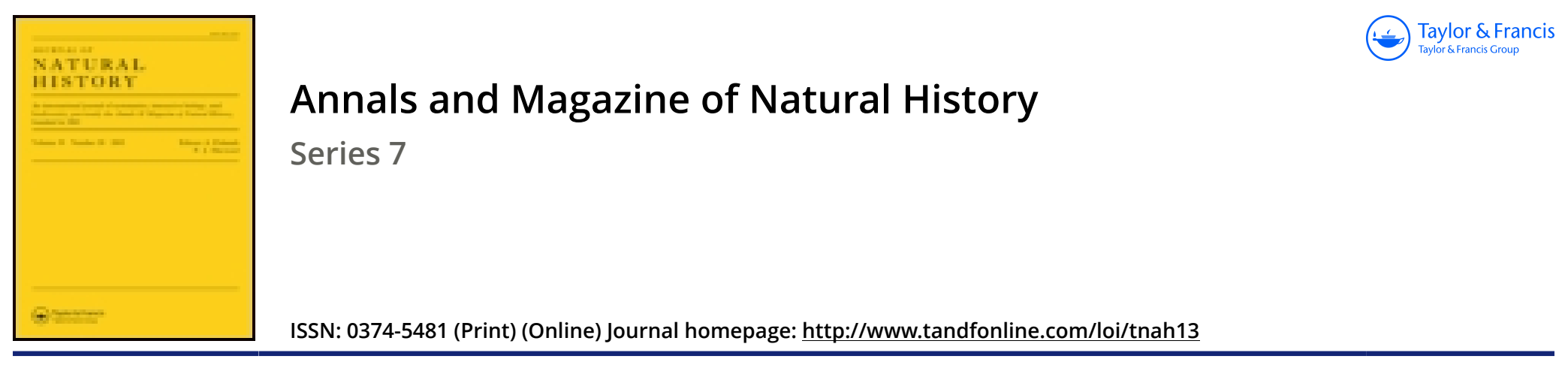

\title{
III.-New genera and species of Coccidæ, with notes on known species
}

\section{T.D.A. Cockerell}

To cite this article: T.D.A. Cockerell (1902) III.-New genera and species of Coccidæ, with notes on known species, Annals and Magazine of Natural History, 9:49, 20-26, DOI: 10.1080/00222930208678531

To link to this article: http://dx.doi.org/10.1080/00222930208678531

册 Published online: 28 Sep 2009.

Submit your article to this journal \lceil

Џ Article views: 3

Q View related articles $\sqsubset$

4 Citing articles: 6 View citing articles 둔 
Linn. Soc. i. p. 66), leaving A. roscidus in as the type. This species has been identified by Thorell (1873) as Drassus segestriformis, Dufour, 1820 ; and this specific name therefore has priority, for though it is doubtful what species segestriformis really is, we must take the first identification as correct.

Type, Amaurobius roscidus, C. L. Koch,=Drassus segestriformis, Dufour, 1820.-Europe.

Cavator, Blackwall, Proc. Linn. Soc. i. p. 66 (1840).

A single species was originally referred to this genus:Clubiona saxatilis, Blackwall.

The name Cavator becomes a synonym of Amaurobius, if $A$. segestriformis (Duf.) and A. atropos (Walck.) are regarded as congeneric.

Type, Cavator saxatilis (Blackwall) $=$ Drassus atropos, Walckenaer, 1830.-Europe.

Ciniflo, Blackwall, Ann. \& Mag. Nat. Hist. vol. vi. p. 229 (1840).

A single species was originally referred to this genus:Clubiona atrox, Latreille.

Since the name Amaurobius has now been restored to its original signification the name Ciniflo must also be restored, and under it will be included the species which have usually been referred to Amaurobius.

Type, Ciniflo atrox (Latreille) = Aranea fenestralis, Stroem. -Europe.

Ccelotes, Blackwall, Trans. Linn. Soc. xviii. p. 618 (1841)

A single species was originally referred to this genus, Drassus saxatilis, Blackwall-a species which had already been referred to the genus Cavator by Blackwall.

The name Calotes therefore becomes a synonym of Cavator, both being now synonyms of Amaurobius.

Type, Coelotes saxatilis (Blackwall) =Drassus atropos, Walckenaer, 1830.-Europe.

III.-New Genera and Species of Coccidæ, with Notes on known Species. By T. 1. A. COCKERELL.

AlL measurements of legs, antennæ, \&c. are in $\mu$. The tarsus is measured without the claw.

Ripersia sporoboli, sp. $\mathrm{n}$.

q. $-2 \frac{1}{2}$ millim. long, 1 broad; much elongated, broad 
posteriorly, narrowing anteriorly, with the anterior end pointed, the head being the narrowest part of the whole insect; abdomen very distinctly segmented; colour very dark purple-grey ; insect entirely covered by a white cottony secretion, in which are laid many pale pinkish eggs, which are rather more elongate than is usual in the genus.

Whole insect very free from hairs, except the caudal region, which is quite hairy. Legs not hairy. No noticeable caudal tubercles nor especially large caudal bristles. Hairs of anal ring six, about 75 long. Labium very short and broad, length 60 , breadth 78 . Middle leg with femur + trochanter 108 , tibia 60 , tarsus 45 ; width of femur 33 . This is from a female which had laid eggs; another, containing embryos, had femul + trochanter 99 , tibia 42 , tarsus 42 ; width of femur 27. It would seem that an immature form of leg may last until a very late period.

Antennæ $192 \mu$ apart, six-jointed, joints measuring : (1) 2430 , (2) 27, (3) 24-30, (4) 18, (5) 21-27, (6) 45-51.

đ.-Dark-coloured, about 430 long (when dry); antenna normal; wings long, length about 800 . The only male found was dead and shrivelled.

Hab. On stems of Sporobolus depauperatus (Torrey), this grass kindly identified for me by Mr. E. D. Merrill. Arroyo Pecos, Las Vegas, New Mexico, Oct. 5, 1901.

The antennæ are remarkably small and resemble in measurements those of $R$. serrata or the penultimate stage of $R$. viridula; but these insects are in other respects very different.

In all things $R$. sporoboli is most nearly related to $R$. festuca, Kuwana. For purposes of comparison I have made the following measurements of an example of festucee having 6-jointed antennæ, received from Mr. Kuwana:-

\section{Ripersia festuce, Kuwana, 1901.}

Labium 72 long, 90 broad. Middle leg: femur +trochanter 180 , tibia 120 , tarsus 66 . Antennal segments : (1) 42, (2) 45, (3) 54, (4) 27, (5) 33 , (6) 75 . This species is found in California.

\section{Dactylopius salinus, sp. n.}

9.-Grey, with some white secretion; six caudal tassels and two cephalic ones. Boiled in liquor potasse turns crimson; legs and antennæ ferruginous. Mounted specimen about 2830 long, 1350 broad. Skin with numerous small round glands and a very few hairs; no distinct caudal 
tubercles; bristles of anal ring very short, about 42 long; caudal bristles very short, not or hardly longer than the spines; legs quite hairy; claw with no denticle on inner side; claw-digitules filiform.

Middle leg : femur + trochanter 255, tibia 195 , tarsus 75 ; width of femur 57.

Labium dimerous, long and narrow; length 135, breadth 75 .

Antennæ 8-jointed, about 285 apart ; measurements of joints : (1) 60, (2) $54-60$, (3) $51-54$, (4) 36, (5) 39-42, (6) $39-45$, (7) $36-39,(8) 75-78$.

Larvæ in female very long and narrow: length 396 , breadth 162. Half-grown examples are still long and narrow: length 1500 , breadth 660 .

Hab. On grass on cliffs by the sea, La Jolla, California, Aug. 6, 1901 .

A distinct species, having the shape of a Pergandiella when young. It resembles $D$. aphyllonis and $D$. quercus in the red colour it gives on boiling, but otherwise it is quite distinct. The antennæ come nearest to $D$. neomexicanus.

\section{Dactylopius neomexicanus, Tinsley, var. $\beta$.}

f.-Pale dull yellowish, covered with a mealy secretion; segmentation conspicuous; no lateral tassels; quite hairy; caudal tubercles well-marked, with bristles about 180 long; bristles of anal ring about 90 long. Middle leg: femur + trochanter 180 , tibia 120 , tarsus 66 . Antennal segments: (1) 39, (2) 39, (3) 33-35, (4) 21-24, (5) 24-27, (6) 24-27, (7) $27,(8) 72$.

Immature form.-Antennæ 6-jointed: (1) 30, (2) 30 , (3) 42, (4) 21, (5) $21,(6) 63$. Joint 3 is inclined to be divided into two, measuring 28 and 14 ; joint 5 is cup-shaped.

Middle leg: femur + trochanter 105, tibia 66, tarsus 62 . The legs are quite stout, the breadth of the middle femur being 57 to 60 , of middle tibia 33 . The anterior legs are by no means so broad.

$H a b$. Crowded at extreme base of stem of some Composite plant, apparently Erigeron. Beulah, New Mexico, 8000 feet (Wilmatte P. Cockerell).

This is possibly a distinct species, but the antennæ are practically as in neomexicanus, and the same may be said of the legs. 'The immature form has legs much like a Ripersia (except in the proportions of tibia and tarsus), and its antenna closely resemble those of $R$. candidata and $R$. confusella, though in these two joint 5 is always longer than 4 . It seens that hipersia is certainly a more primitive type 
than Dactylopius, the latter passing through a Ripersia-stage in the course of its development.

\section{Eriococcus Palmeri, Ckll., var. a.}

q. -Without ovisac very dark red, with white bristles at sides posteriorly ; dorsum not bristly; antennæ and legs ferruginous. Ovisac pure white, about 3 millim. long, often smaller.

Largest dermal spines 48 long. Front leg with femur + trochanter 174, tibia 102, tarsus 117 ; hind leg with femur + trochanter 192, tibia 120, tarsus 129 ; claw with a minute denticle near tip. Caudal tubercles about $90 \mathrm{long}, 60$ broad at base. Antennæ 6-jointed, formula 3 (1 2) 645 , or 3 (6 2 1) (4 5). Segments: (1) 30, (2) 30, (3) 75, (4) 21-24, (5) 21, (6) 27-30.

Hab. La Jolla, California, Aug. 7, 1901, clustered on twigs of Eviogonum fasciculatum, Bentham.

E. Palmeri is new to the U.S. fauna.

\section{Crssococcus, gen. nov.}

Belongs to the Eriococcini. Larva typically Eriococcine, with rows of dorsal spines and prominent caudal tubercles; legs slender, claw very long; anal ring with long bristles; antenna 6-jointed, last joint short, third longest. Adult living in a cup-shaped gall ; mouth-parts minute but well developed; legs and antennæ rudimentary; anal region strongly chitinous, with a pair of plates simulating those of the Lecaniinæ.

Type C. Fulleri.

\section{Cissococcus Fulleri, sp. n.}

Galls in clusters on branches of Cissus cuneifolia; gall cup-shaped, with the top flat, with a minute central orifice. Diameter of gall about 6 millim., height 5 millim.

9.-Produces a small amount of cottony secretion. Skin colourless, with numerous small dark chitinous protuberances; a few hairs and circular glands, the latter having lines radiating from a central circle, or (differently focussed) ten dots arranged around a central dot. Trachea and spiracles large and prominent. Mouth-parts minute but well developed. Legs rudimentary, about $105 \mu$ long, stout, with the claw and digitules well developed; tarsus extremely short, much broader than long. Anal region dark, strongly chitinous, with an elongated-oval structure, pointed apically, consisting of two contiguous plates, which are covered with tubercles bearing stout bristles, recalling the armature of a pine-apple. 
This is set in a deep oval cavity, open posteriorly, the edges of which are strongly chitinized. The contiguous edges of the plates towards the base have a wavy outline, the convexities of one side fitting the concavities of the other.

Embryonic larva bright crimson after boiling in liquor potassæ.

Hab. Umquahumbi Valley, S. Africa (Claude Fuller).

It is infested by a dipterous parasite, the puparia of which were found in the galls.

\section{Pseudolecanium digitatum, sp. n.}

q.-Pyriform, with the hind end pointed; about $2 \frac{1}{2}$ millim. long; dark ferruginous, shiny, producing some cottony material. End of abdomen strongly chitinized, with the form usual in the genus. The diagnostic characters, as in all species of the genus, are derived mainly from the larva, the female being a mere bag of eggs.

Larva extremely long and narrow, length 600 , breadth $160 \mu$. Anterior extremity truncate, crenulate, with six short, blunt, finger-tip-like spines; a row of fifteen blunt spines down each side of body ; no dorsal spines ; legs well developed, anterior tibia 60 , its tarsus $39 \mu$ long; the tibia has a constriction about 27 from base, making it look almost 2 -jointed, this being more or less apparent on all the legs; tarsal digitules long, with small knobs; claw-digitules shorter, filiform, knobbed. Antennæ 24 apart at base and $30 \mu$ from anterior end of head; 6-jointed, joints measuring: (1) 18 , (2) 12, (3) 27-33, (4) 20, (5) 21, (6) 30. Anal ring small, circular, without bristles on its margin, but posterior to it are set four bristles, of which the inner two are shortest; anterior to anal ring is a row of four finger-like blunt spines; on each side is a caudal bristle, about $1 \leqslant 0 \mu$ long, and beyond each of these a pair of finger-like spines; anterior to and a little laterad of each caudal bristle is a small round gland. The last two segments have each a pair of bristles on the ventral surface, those on the last being twice as long as those on the penultimate segment.

Hab. On leaves of grass, Richmond, Natal (Claude Fuller, no. 2). It has a Chalcidid parasite.

The genus Pseudolecanium is new to Africa.

Epicoccus, gen. nov.

Belongs to the Dactylopiini. Anal ring without hairs. Adult female with legs and antennæwell developed; antennæ $6-$ jointed, cylindrical, last joint long. 
Type Epicoccus acacice (Coccus acacice, Maskell, Tr. N. Z. Inst. xxix. p. 319). Australian.

This is near the stem-form from which Spharococcus must have been derived.

\section{LuZuLASPIS, n. n.}

Signoretia, Targioni-Tozzetti; not of Stal, 1860.

'Iype Luzulaspis luzulae (Aspidiotus luzulec, L. Dufour; Signoretia clypeata, Targ.). European.

\section{Phenacaspis natalensis, sp. n.}

9.-Scale white, about 3 millim. long, pyriform; exuviæ pale orange-brown.

Five groups of circumgenital glands ; median of 10 , antevior laterals 22-26, posterior laterals 19-26. Anal and genital apertures opposite. Median lobes large, widely diverging, broader than long, the long inner margin strongly serrulate; their bases well apart, the space occupied by the usual pair of short spines. Second lobe represented by three elongated and rounded lobules, the first of which is largest and bears a spine. Third lobe represented by a very long narrow lobule bearing a spine, followed by a broad and much shorter lobule, and then a very broad serrulate lobule, having its outer slope much the longest. The fourth lobe is represented by a triangular lobule bearing a spine and two slight swellings of the margin, too slight to be called lobules.

万. - Scale feebly tricarinate or barely keeled at all.

$H a b$. Durban, Natal, abundant on underside of leaves of mango (Claude Fuller, no. 25).

Closely allied to Phenacaspis chinensis (Chionaspis chinensis, Ckll. Rep. Cal. Bd. Hort. v. p. 37), but the median lobes are more sloping. Of the Ceylon species described by Green it comes nearest to Phenacaspis megaloba (Chionaspis megaloba, Green, 'Coccidæ of Ceylon,' pt. ii. 1899); but megaloba has two lobules in place of the slight swellings of the fourth lobe described above, and differs also in the position of the anal and genital orifices.

Hemichionaspis cyanogena, Ckll., 1901.

A new locality is Verulam, Natal (Fuller, no. 13).

Odonaspis secretus, var. Greenii, nov.

Aspidiotus secretus, Green, Coccidæ of Caylon, pt. i. p. 64. (Hab. Ceylon.)

Green and Maskell have pointed out distinctions between 
the Ceylon and Japan forms of $O$. secretus, but unfortunately a varietal name (lobulata, Maskell) has been applied to the Japanese insect, which is the true secretus.

\section{Monophlebus Championi, sp. $\mathrm{n}$.}

Monophlebus sp., Ckll., Biol. Centr.-Amer., Coccidæ (1899), p. 3, middle of page.

This name is proposed for the species described in the place cited from a male, having only four fleshy processes on the abdomen. It was hoped that the female might be obtained; but as this now seems unlikely, it is best to give a name to a species so strongly distinguished.

\section{Cryptophyllaspis Rübsaameni, sp. $\mathbf{n}$.}

Gall sinall, cylindrical, about 2 millim. long, thickly clustered on leaves of Codiaum.

q.-Orange, oblong, caudal end sunken, overlapped at the sides by lobiform projections; no circumgenital glands; anal orifice broad-oval, about $17 \mu$ long, and distant about $39 \mu$ from bases of median lobes; lobes and squames formed as in $C$. occultus (Green); three pairs of lobes, not even the median ones darkened in the least; median lobes slightly notched on each side; squames narrow and pointed, strongly fringed; beyond the third lobe are three double squames, each having the appearance of two squames united basally; spines small.

Hab. Bismarck Archipelago; received from Mr. E. $\mathbf{H}$. Rübsaamen.

I sent a copy of the description to Mr. Rübsaamen, to be published in connexion with his studies of galls, but it seems desirable that it should also appear in a papor devoted to Coccidæ.

East Las Vegas, New Mexicu, U.S.A., Oct. 31, 1901.

IV.-The" Cahow" of the Bermudas, an Extinct Bird. By A. E. VERRILL.

DuRing my two recent visits to Bermuda I made special investigations in regard to the history and identity of the "cahow" or "cohowe," a bird described by the earliest settlers as very abundant and easily captured, so that its Hesh and eggs were largely used as food. Indeed, had it not 